Vojislav Martinov

Muzej Vojvodine

Novi Sad, Srbija

vojislav.martinov@muzejvojvodine.org.rs
DOI: https://doi.org/10.18485/slovenika.2017.3.1.3

UDK: 314.15-026.48(=163.6)(497.113)"18/19"

622.33.013(497.11)(091)

Pregledni rad

\title{
Slovenačka polka na Fruškoj gori: slovenački rudari u rudniku uglja u Vrdniku
}

Sažetak

Prvi slovenački doseljenici u selo Vrdnik stigli su sedamdesetih godina XIX veka, kao stručna radna snaga za potrebe eksploatacije novootvorenih kopova rudnika uglja, u vlasništvu zagrebačke preduzetničke porodice Pongrac. U manjim talasima, doseljavanja slovenačkih rudara nastavljena su i početkom XX veka, prateći ekspanziju rudnika, koji je doživeo svoj vrhunac u razdoblju između dva svetska rata. $\mathrm{U}$ ovom radu će biti dat kratak istorijski prikaz doseljavanja (i iseljavanja) slovenačkog stanovništva, sa akcentom stavljenim na karakteristike njihovog života $u$ višenacionalnom industrijsko-agrarnom Vrdniku, kao i na materijalna svedočanstva o kulturnom životu rudarske zajednice u celini.

Ključne reči: industrijsko nasleđe, Slovenci, istorija rudarstva, Vrdnik

Među novije trendove na polju heritologije svakako spada i valorizacija industrijskog nasleđa i njegovih kulturnih i turističkih potencijala. $U$ fokusu muzealizacije ovog nasleđa prvenstveno se nalaze materijalni tragovi industrijalizacije - mehanizacija, industrijska arhitektura, prostorno-arhitektonske celine. Antropološkim produbljivanjem koncepta industrijskog nasleđa, $\mathrm{u}$ okvire istraživanja ulazi i nematerijalna baština vezana za kulturu proletarijata, kao karakteristične društvene grupe formirane $u$ epohi industrijalizacije (Petrović 2013, 96-120). ${ }^{1}$

\footnotetext{
${ }^{1}$ Kritički osvrt na globalne i lokalne aspekte negovanja industrijskog nasleđa, iz kojeg je apstrahovano nasleđe radničke klase, videti u: T. Petrović, Museum and Workers: Negotiating Industrial Heritage in the Former Yugoslavia, Narodna umjetnost, 50/1, 96-120.
} 
Interesovanje za industrijsko nasleđe u Republici Srbiji novijeg je datuma, čime se može objasniti gotovo potpuno odsustvo ozbiljnijeg proučavanja prošlosti rudnika mrkog uglja „Vrdnik“, kao jednog od najznačajnijih industrijskih lokaliteta na teritoriji AP Vojvodine. Široj stručnoj i naučnoj javnosti je u velikoj meri nepoznato kompleksno nasleđe fruškogorskog naselja Vrdnik, koje postepeno iščezava. ${ }^{2}$ Samim tim, do danas je izostalo sistematsko i stručno proučavanje rudarske zajednice $u$ Vrdniku, koja je nakon više od jednog veka prisutnosti ostavila duboke tragove $u$ ovom naselju, a koji su opstali do danas, pedeset godina nakon zatvaranja rudnika.

Ovom prilikom akcenat će biti stavljen prvenstveno na slovenački segment rudarske zajednice $u$ Vrdniku, mada je teorijski, ali i istorijski, neopravdano interpretirati prošlost i nasleđe slovenačkih rudara van okvira rudarske zajednice u celini. Naime, karakteristi$\mathrm{ku}$ radničke klase u periodu razvijene industrijalizacije, a naročito rudarskih kolektiva, predstavlja izražen nadnacionalni identitet. Rudarenje i rudari su zajednica poziva, koja „iako sastavljena od pripadnika različitih naroda, zajedničkim 'profesionalnim' težnjama, specifičnostima poziva, terminologijom koju koristi, odnosom prema radnom habitatu i upravi, poprima elemente identiteta 'nadređenog etničkome“" (Matošević 2011, 57).

\section{Kratak istorijat rudnika mrkog uglja „Vrdnik“}

Najranije pominjanje nalazišta uglja u Vrdniku potiče iz izveštajâ inspektora iločkog vlastelinstva J. Handela, pisanih 1782. godine. Rudnik se nalazio u posedu manastira Ravanica, koji je prvi i počeo sa njegovom površinskom eksploatacijom, godine 1804. Franc Šams, petrovaradinski apotekar i geolog amater, obišao je 1806. godine nalazište uglja kod Vrdnika i tom prilikom konstatovao da ugljenokop izgleda zapušteno, primitivno i van nadzora rudarskih stručnjaka. Takođe, konstatovao je da je problem transporta uglja teško rešiv zbog lošeg prilaznog puta do „provalije“ ili „uvale“ u kojoj se nalazi potkop (Šams 2013, 102-103). Prepiska mitropolita Ste-

${ }^{2}$ Zapravo, prve inicijative za osnivanje Muzeja rudarstva u Vrdniku mogle su se čuti neposredno nakon zatvaranja rudnika, tokom sedamdesetih godina XX veka, ali se nikada nije stiglo dalje od tih predloga. Poslednju inicijativu za formiranje muzeja pokrenuo je 2014. godine Sekretarijat za kulturu i informisanje AP Vojvodine, ali su sa političkim promenama usledili i novi prioriteti, koji su ovaj projekat stavili ad acta. 
fana Stratimirovića sa Carskom rudarskom direkcijom (od 1806. do 1808. godine), u kojoj se traži stručna pomoć i angažovanje iskusne radne snage, svedoči o zainteresovanosti Karlovačke mitropolije za ozbiliniju eksploataciju ugljenokopa. U prvoj polovini XIX veka, razvoj kapitalističke privrede $\mathrm{u}$ Habsburškoj monarhiji bio je tek $\mathrm{u}$ začecima. Privredni, socijalni i politički uslovi za razvoj industrijske eksploatacije ruda bili su još uvek nepovoljni, što se odrazilo i na rudnik u Vrdniku. Od 1817. godine rudnik je prestao sa radom, a novi pokušaji njegove eksploatacije javljaju se tek nakon što je vlastelinska porodica Pejačević iz Rume 1845. godine kupila od manastira Ravanica koncesiju na rudnik.

Počeci modernizacije rudnika vezuju se za dolazak iskusnog industrijalca, zagrebačkog plemića slovenačkog porekla - Gvida Pongraca, koji je od porodice Pejačević preuzeo kontrolu nad rudnikom 1871. godine, a puno vlasništvo stekao 1883. Gvido Pongrac i njegov sin Gustav obezbedili su savremenu mehanizaciju, a nakon terenskog istraživanja vrdničkog basena pristupilo se intenziviranju iskopavanja uglja i otvaranju dubinskih okana. Osavremenjivanje eksploatacije podrazumevalo je i angažovanje stručne i iskusne radne snage. Već tokom sedamdesetih godina XIX veka, u Vrdnik se doseljavaju rudari iz raznih krajeva Austrougarske. Među novim stanovnicima Vrdnika najbrojniji su bili Slovenci, a potom Hrvati, Bosanci, Česi, Mađari i pojedini pripadnici drugih naroda. Kako bi privukao što veći broj rudara, Gustav Pongrac je morao da obezbedi minimalne uslove za njihovu egzistenciju. Tokom 80-ih godina on izgrađuje prvu rudarsku koloniju (Stara kolonija), rudarsku ambulantu i osnovnu školu na hrvatskom jeziku, za potrebe obrazovanja dece iz rudarskih porodica. Od presudnog značaja za komercijalnu eksploataciju rudnika bila je izgradnja pruge Vrdnik-Ruma, koja je značajno olakšala i ubrzala transport uglja.

Zapavši u ekonomske probleme, Gustav Pongrac je bio prinuđen da proda vlasništvo nad rudnikom vladi Ugarske. Kao državni rudnik, Vrdnik je nastavio da prosperira, a izgradnjom Nove kolonije poboljšani su uslovi života sve brojnijeg rudarskog kolektiva. Na Novoj koloniji podignuta je još jedna osnovna škola za novonaseljene mađarske porodice. Izgradnjom termoelektrane omogućena je elektrifikacija Vrdnika, dalja modernizacija mehanizacije i prelazak sa parnog na električni pogon, što je dodatno pospešilo eksploataciju kopova. U godinama mađarske uprave dolazi i do izgradnje čuvene „Kasine“ - secesijskog zdanja podignutog u centru Vrdnika, koje je postalo središte rudarskog društvenog života (Dom rudara). Za sve 
brojniju upravu rudnika podignut je i niz od deset komfornih vila, poznat u Vrdniku kao „činovnički“ ili „gospodski red“.

Formiranjem Kraljevine Srba, Hrvata i Slovenaca (Kraljevine Jugoslavije), kontrolu nad rudnikom preuzima nova država. Zbog učestalih štrajkova, rudnik je u jednom momentu stavljen pod vanrednu vojnu upravu, kako bi se stabilizovao proces proizvodnje i pacifikovao radnički bunt, uzrokovan teškim socijalnim stanjem i revolucionarnim kretanjima u srednjoj Evropi nakon završetka Prvog svetskog rata.

U međuratnom razdoblju rudnik je nastavio da se razvija, otvarana su nova okna za eksploataciju uglja, a produkcija je bila u usponu. U Glavnom - južnom oknu radilo se na dubini od 270 metara, što je bilo najdublje okno na celom Balkanskom poluostrvu (Ostojić 1989, 84). Prilikom daljeg produbljivanja ovog okna, 5. oktobra 1931. godine, naišlo se na termalne vode koje su ga u potpunosti poplavile. Ova velika havarija i zahuktala ekonomska kriza smanjile su produktivnost rudnika, u kojem je 1934. godine radilo svega 540 radnika (Vulin 2010, 83).

Tokom Drugog svetskog rata rudnik je bio pod kontrolom Nezavisne države Hrvatske. Zbog njegovog značaja za privredu NDH, čitav Vrdnik je sve do povlačenja okupatora, oktobra 1944. godine, bio pretvoren $\mathrm{u}$ čvrsto utvrđenje, kako bi se omogućila nesmetana eksploatacija uglja.

U novoj, Federativnoj Narodnoj Republici Jugoslaviji rudnik je nastavio sa radom kao privredno preduzeće od 1946. godine. Već prvih godina rudari su pokazali veliki entuzijazam u obnavljanju zemlje i 1947. se posebno isticali svojim udarničkim podvizima. Od 1950. godine rudnik je u vlasništvu Narodne Republike Srbije, a čitavo preduzeće proširuje svoju delatnost i na izvođenje rudarskograđevinskih radova i u drugim rudnicima FNRJ (Vulin 2010, 84). Krajem 50-ih godina je produkcija rudnika bila u opadanju, što je uzrokovalo ponovno smanjenje broja zaposlenih, kojih je 1958. bilo 701 , a na kraju 1960. godine - svega 595. Pokušaji produktivnije eksploatacije tokom 60-ih nisu urodili plodom zbog sve težeg terena i pristupa uglju i drugih pratećih problema (pojava gasova i vode $u$ oknima, smanjenje kvalifikovane radne snage, negativno poslovanje celokupnog preduzeća, niske plate i loš kvalitet uglja). Svi ovi faktori uticali su na to da se rudnik zvanično ugasi i prekine sa radom 1968. godine (Vulin 2010, 99-100). 


\section{Martinov \\ Slovenačka polka na Fruškoj gori:...}

\section{Današnje stanje industrijskog nasleđa rudnika mrkog uglja „Vrdnik“}

Pedeset godina nakon zatvaranja rudnika mrkog uglja, u Vrdniku nije ostalo mnogo očiglednih tragova koji ukazuju na njegovu značajnu industrijsku prošlost. Stara mehanizacija je nakon zatvaranja rudnika premeštena u druge, aktivne rudnike, rudarska okna su zapečaćena, pruga Vrdnik-Ruma je ukinuta, a šine i pragovi izvađeni. Stara i Nova kolonija i dalje su nastanjene, ali su na većini objekata izvršene adaptacije koje su izmenile originalan izgled ovih naselja, građenih po univerzalnim, utilitarnim principima srednjoevropske industrijske arhitekture. Termoelektrana, koja se nalazi u Centralnom registru spomenika kulture (Centralni registar spomenika kulture, SK 1292), u potpunosti je uništena 1999. godine. Nakon blažeg oštećenja uzrokovanog NATO bombardovanjem, objekat je devastiran od strane lokalnog stanovništva. Novija mehanizacija, , gospodski red“ i još neki objekti bez značajne kulturno-istorijske vrednosti danas su formalno u privatnom vlasništvu, nakon privatizacije $\mathrm{Ru}-$ dničko-građevinskog preduzeća „Vrdnik“.

Kao najreprezentativniji relikt prvog talasa industrijalizacije Vrdnika, do danas se očuvala zgrada „Kasine“, koja je i nakon zatvaranja rudnika imala društvenu funkciju. U jednom delu objekta nalazi se kancelarija Mesne zajednice, potom kancelarije nevladinih organizacija, a na spratu su biblioteka i plesna dvorana. U prethodnih nekoliko godina sprovedena je i rekonstrukcija čitavog objekta pod stručnim nadzorom Zavoda za zaštitu spomenika.

O multikulturnoj prošlosti Vrdnika možda i najviše svedoči „Rudarsko groblje“, koje se nalazi u neposrednoj blizini Specijalne bolnice za rehabilitaciju i hotela „Termal“. Zbog izgradnje banjskoturističkih objekata, groblje nije očuvano u celosti. Projekat njegove obnove, rađen početkom 2008. godine, finansirao je pokrajinski Sekretarijat za energetiku i mineralne sirovine. Izradu i postavljanje metalne ograde i kapije finansirao je Sekretarijat za kulturu, a radovi na uređenju groblja kompletno su okončani krajem 2009. godine.

U projektu Zavoda za kulturu Vojvodine, sprovedenom tokom 2014. godine pod nazivom „Novi kreativni prostori Vojvodine“, pored zgrade „Kasine“, kao objekti od potencijalnog kulturno-turističkog značaja u Vrdniku detektovane su zgrada stare škole na Novoj koloniji i zgrada stare rudarske konjušnice, iznad hotela „Termal“ (Dević i dr. 2015, 17-18). Karakteristično za verski život svih rudarskih zajednica u centralnoj Evropi jeste negovanje kulta Svete Varvare, patrone rudara i zaštitnice „dobre smrti“. Prva kapela Svete 
Varvare pominje se 1895. godine, ali nije precizirana njena lokacija. Prema nekim izvorima, kapela se nalazila neposredno pored ulaza $u$ Južno okno. Nova kapela je otvorena u krilu osnovne škole u Novoj koloniji. Nakon zatvaranja rudnika 1969, u sporazumu sa školskom upravom, prostor kapele je u celosti prepušten školi u zamenu za napušteni objekat bivše rudarske ambulante. Kapela je tom prilikom ponela naziv Blaženog Nikole Tavelića, ali je među katolicima u Vrdniku ostao običaj da na ovom mestu obeležavaju Dan Svete Varvare. Kapela je i danas poznata pod tim imenom, a zaslugom sremskog vikara Đure Gašparovića ona je i obnovljena devedesetih godina XX veka (Dević i dr. 2010, 110-113). Proslava Dana Svete Varvare kontinuirano se obeleževa od 80-ih godina i ima ekumenski karakter. Svečanoj misi, pored katolika, često prisustvuju vernici pravoslavne i muslimanske vere, predstavnici Srpske pravoslavne crkve, Mesne zajednice i Rudarsko-građevinskog preduzeća (RGP) „Vrdnik“ (Dević i dr. 2010,114).

Ono što će ostati kao trajno nasleđe Rudnika mrkog uglja jesu brojne porodice nastale iz mešovitih brakova, sklapanih kako unutar rudarske zajednice tako i sa starosedelačkim, mahom srpskim stanovništvom Vrdnika. Potomci, ali i još uvek živi radnici rudnika trude se i danas da održe i da reaktiviraju sećanje na industrijsku prošlost Vrdnika. To posebno dolazi do izražaja na Dan rudara, koji se u Vrdniku obeležava svake godine 6. avgusta, i koji ima svoju zvaničnu i nezvaničnu manifestaciju. Uz podršku lokalnih organa samouprave, memorijalno Udruženje rudara „Vrdnik“ ceremonijalno obeležava ovaj datum, uz polaganje venaca na „rudarskom groblju“ i prateći kulturni program. Paralelno sa oficijelnom svečanošću, $u$ naselju Stara kolonija se istoga datuma održava i neoficijelno slavlje, $\mathrm{u}$ organizaciji samih stanovnika kolonije, mahom potomaka vrdničkih rudara.

\section{Slovenačka zajednica u Vrdniku}

Doseljavanje Slovenaca u Vrdnik vezano je za preuzimanje rudnika od strane Gvida Pongraca. Prema posrednim svedočenjima autora monografije Nepokoreni - hronika Vrdnika i okoline, Milenka Ostojića, prva organizovana grupa od 90 Slovenaca naselila se ovde 1875. godine na poziv „birmanca“ (osoba zadužena za regrutaciju radne snage) - Mihajla Lesjaka. Na osnovu raspoloživih izvora teško je rekonstruisati kako je dalje teklo naseljavanje rudnika, ali značajan dokument je Popis vrdničke bratovštine (sindikalnog udruženja), u kojem se nalazi spisak 131 radnika zaposlenog u Pongracovom 
rudarskom preduzeću do 1907. godine, kada dolazi do državnog preuzimanja rudnika (Marković 2014, 368). Na spisku se nalaze brojna slovenačka imena, poput Adolf Babnik, Josip Zdouc, Agošton Seničar, Matija Kranjc, ali je teško ustanoviti njihov konačan broj bez pratećih informacija o mestu porekla, jeziku, etničkoj pripadnosti.

Rudarsku zajednicu karakteriše velika mobilnost, relativno lako menjanje mesta boravka, $\mathrm{u}$ zavisnosti od sveukupnih uslova života pri određenom rudniku. Tako su se, krajem Prvog svetskog rata i sa formiranjem Kraljevine Srba, Hrvata i Slovenaca, brojni rudari iselili iz Vrdnika i vratili u matične države. Ova migracija je uzrokovala veliku nestašicu radne snage, tako da je tokom dvadesetih godina usledio novi talas doseljavanja, prvenstveno iz rudarstvu vičnijih krajeva Kraljevine SHS - Slovenije, Istre i Bosne i Hercegovine. O ovim turbulentnim promenama svedoče i popisi stanovništva. Pri popisu iz 1910. godine, u Vrdniku je živelo 4.012 stanovnika. Nakon Prvog svetskog rata, tačnije - 1921. godine, zabeleženo je svega 2.644 stanovnika, da bi već 1931 . broj opet narastao na 4.040 (Ostojić 1989, 21). Ovako velike oscilacije svedoče i o visokom procentu vrdničkog stanovništva koje je bilo direktno vezano za funkcionisanje rudnika.

Teško je danas ustanoviti koliko je među ukupnim brojem rudara bilo Slovenaca. Jedan od mogućih izvora su matične knjige članova mesne bratinske blagajne Vrdnik, koje se čuvaju u Istorijskom arhivu Srema u Sremskoj Mitrovici. ${ }^{3}$ Među rubrikama koje su se vodile za svakog člana dati su i podaci o mestu rođenja. Takođe, navođeno je i bračno stanje radnika, kao i broj dece. Na osnovu ovih informacija moguće je, makar delimično, rekonstruisati etničko poreklo rudara. Problem je u tome što su, $\mathrm{u}$ vreme kada su vođene ove Matične knjige - krajem dvadesetih godina XX veka, mnogi rudari već bili pripadnici druge ili čak treće generacije nastanjene $u$ Vrdniku. Pritom, ne treba isključiti ni brojne mešovite brakove do kojih je sigurno dolazilo.

Ipak, kada se posmatra društveni život vrdničkih rudara, može se steći utisak da je upravo slovenačka zajednica bila ta, možda i zbog svoje brojnosti, koja je ostavila najviše traga u njihovoj svakodnevici. Kako u svojoj knjizi navodi M. Ostojić, običaj maškara upravo su Slovenci doneli u Vrdnik. Po njegovom svedočenju, maškare su se održavale četiri dana pre Poklada, kada se pravila lutka od slame

\footnotetext{
${ }^{3}$ Istorijski arhiv Srem. Sremska Mitrovica. F. br. 345 Rudnik mrkog uglja „Vrdnik“(1804-1968), Matične knjige, Del. br. 118-123.
} 
koja je simbolizovala pokojnika (uvek je imao ime Matija), koju je maskirana kolona rudara vodila na nosilima. Čitav događaj bio je simulacija posmrtne povorke, u kojoj su bile stalne uloge „popa“, „đavola“ $i$ „merača rake za pokojnika“. Kolona bi se zadržavala ispred izabranih kuća i kopala raku za „pokojnika“ sve dok domaćin kuće ne bi dao prilog u novcu ili hrani. Manifestacija bi se završavala na Staroj koloniji, gde bi se lutka palila i nastavljalo slavlje uz pratnju rudarske muzike (Ostojić 1989, 71-73).

Rudarska zajednica u Vrdniku imala je svoj „rudarski orkestar“ još od 1891. godine, a ova tradicija očuvala se do zatvaranja rudnika, 1968. godine. Ovaj orkestar je svirao tzv. bleh-muziku na limenim instrumentima i priređivao redovne koncerte na Dan rudara, Dan Svete Varvare, Prvi maj i druge značajne datume. Koncerti su se održavali po ulicama Vrdnika i u zgradi „Kasine“, gde se nalazi i plesna hala, a orkestar je predvodio i sve značajne rudarske procesije. Članovi orkestra mahom su bili Slovenci, a to svedoče i malobrojne preostale notne sveske koje se danas čuvaju u Srpskoj čitaonici u Irigu, a koje su pisane na slovenačkom jeziku.

Iriška Srpska čitaonica uspela je da sačuva i mali broj knjiga iz nekada brojnog fonda Rudarske čitaonice iz Stare kolonije, uništene tokom Drugog svetskog rata. Inače, na čelu ove čitaonice su se do početka rata nalazili uglavnom Slovenci - Rudolf Babnik, Ivan Stilin i Ivan Benedikt.

Nakon rata, na inicijativu rudara Rudolfa Gregorčiča, formira se prvo slovenačko udruženje - Kulturno-prosvetno društvo (KPD) „Franc Rozman“, nazvano po čuvenom slovenačkom narodnom heroju, stradalom 1944. godine. KPD „Franc Rozman“ (kasnije KUD „Franc Rozman“) delovalo je od 1945. do 1968. godine i razvijenom delatnošću privuklo je u svoje redove i brojne druge stanovnike Vrdnika, bez obzira na njihovu etničku pripadnost. Sedište KUD-a „Franc Rozman“ bilo je u Staroj koloniji, u objektu u kojem je bila smeštena prva rudarska škola. Zahvaljujući pomoći Ministarstva kulture i prosvete Republike Slovenije, $u$ „Francu Rozmanu“ se brzo razvila biblioteka i čitaonica sa brojnim naslovima, dobijen je i radio- aparat „Kosmaj“, kao i instrumenti za orkestar - poklon kolektiva fabrike instrumenata iz Meneša, kod Ljubljane. Zgrada „Franca Rozmana" postalo je mesto za održavanje svih značajnih rudarskih proslava, ali i događaja koji su od opšteg značaja za Vrdnik i okolinu. Reporter Ž. Marković svedoči o posebno zabavnim proslavama berbe grožđa i dočecima Nove godine na koje su dolazili i ljudi iz okolnih mesta, a da pritom nikome nije smetalo to što su se uz zvuke

$$
66
$$




\section{Martinov \\ Slovenačka polka na Fruškoj gori:...}

harmonika, ispod spiralnih raznobojnih traka od krep-papira i celofana, pod vejavicom od konfeta, najčešće čule i igrale slovenačke polke. (Marković 2014, 760-761).

KUD „Franc Rozman“ je uspostavio prisne odnose sa političkim establišmentom tadašnje Socijalističke Republike Slovenije, a najvidljiviji rezultat tih odnosa bile su učestale ekskurzije Vrdničana u Sloveniju, kao i uzvratne posete Slovenaca Vrdniku. Ove ekskurzije bile su organizovane prvenstveno za omladinu, koja je tim putem imala prilike da, tokom letnjih i zimskih raspusta, gostuje u slovenačkim turističkim odmaralištima. Brojni Vrdničani, bez obzira na etničku pripadnost, imali su priliku da gostuju npr. u Poljani kod Škofje Loke, u Žalama, Ormošu, mestu Poljče kod Ljubljane (Marković 2014, 761-762).

Slovenačka zajednica u Vrdniku bila je vodeća i u afirmisanju planinarstva. Prvo posleratno planinarsko društvo na Fruškoj gori „Zmajevac“ osnovano je 1. aprila 1948. godine, a osnivači su bili Teofil Molčko, Mihajlo i Rozina Lesjak, Špira Ožegović, Elza Molčko, Rudolf Gregorčič, Todor Ilkić, Alojz Bevc i drugi. Prvi predsednik bio je, takođe, Slovenac Špiro Paklar. Ovo Planinarsko-sportsko društvo je, uz finansijsku pomoć rudnika, 1955. godine obnovilo razrušeni planinarski dom „Zmajevac“ na Fruškoj gori, koji je i danas u funkciji (Marković 2014, 763).

Nakon zatvaranja rudnika 1968. godine, deo rudara ostao je da radi u Rudarsko-građevinskom preduzeću Vrdnik, koje se specijalizovalo za izvođenje stručnih radova na kopovima širom Jugoslavije, pa čak i u nemačkim rudnicima u Rurskoj oblasti. Većina rudara je, međutim, napustila Vrdnik u potrazi za novim radnim mestom. Deo Slovenaca vratio se u svoju domovinu, a mnogi su se zaposlili u rudnicima u Srbiji - najviše u rudarskom kompleksu Rembas kod Resavice i u Aleksinačkim rudnicima.

Poredeći popise stanovništva iz godina 1971. i 1981, zabeležen je primetan pad broja stanovnika u Opštini Irig, pod koju potpada Mesna zajednica Vrdnik. Sličan pad zabeležen je i među pripadnicima slovenačke manjine. Na popisu 1971. godine, u Opštini Irig je zabeleženo 329 Slovenaca (2,41\%), a 1981. godine - svega 212 Slovenaca $(1,71 \%)$. Međutim, treba uzeti u obzir da etnička pripadnost nije imala veliki značaj u rudarskim kolektivima, u kojima je sklapano dosta međuetničkih brakova, pa se zato indikativnim može smatrati i podatak da je na popisu 1971. godine bilo 314 (2,3\%) deklarisanih Jugoslovena, a 1981. godine - čak $1.128(9,08)$ (Stanovništvo 1982, 12). Prema drugim procenama, 1980. godine je u Vrdniku od 2.593 
stanovnika bilo njih 314 (7,7\%) slovenačke etničke pripadnosti (Dević 2010, 109).

Na osnovu popisa stanovništva 2011. godine, na području Vojvodine primetan je drastično smanjen procenat Slovenaca, koji danas čine svega 0,09\% ukupnog stanovništva. Ovo je uzrokovano dugoročnim procesima depopulacije, započetim 60 -ih godina XX veka (Knežević 2014, 434). Glavnim faktorima depopulacije smatraju se nizak natalitet slovenačke zajednice i brojne migracije $u$ matičnu državu (Knežević 2014, 438- 439). Ipak, u slučaju Vrdnika treba uzeti u obzir i procese asimilacije, uzrokovane brojnim mešovitim brakovima. Mnogi današnji i bivši Vrdničani čuvaju sećanje na svoje slovenačke pretke, a u Rumi je formirano i Slovenačko društvo „Emona“, u kojem se okupljaju i brojni potomci slovenačkih rudara iz Vrdnika.

Slojevito kulturno nasleđe Slovenaca iz Vrdnika i rudarske zajednice $u$ celini ostalo je do danas $u$ velikoj meri neistraženo. Od značajnijih izvora za kulturno-istorijsko proučavanje ove tematike treba izdvojiti privatnu kolekciju porodice Ostojić iz Vrdnika, nastalu sakupljačkim radom zavičajnog istoričara Milenka Ostojića. Brojni materijalni aspekti ove baštine nalaze se i po drugim privatnim kolekcijama potomaka vrdničkih rudara, poput porodice Lesjak iz Sremske Kamenice. Evidentan je kontinuitet održavanja rudarskih običaja, koji je do danas ostao prisutan u Staroj i Novoj koloniji, još uvek nastanjenoj malobrojnim naslednicima rudarske zajednice. Ovaj fenomen svakako zahteva ozbiljniju pažnju stručnjaka i preduzimanje etnokulturoloških istraživanja. Mnoga lična sećanja, kroz svoje reportaže i monumentalnu monografiju „Vrdnik - međunarodna priča“, uspeo je da zabeleži novinski reporter i Vrdničanin Željko Marković. Od institucija koje nam mogu pružiti više informacija i eventualnih materijalnih svedočanstava na temu slovenačke zajednice u Vrdniku treba izdvojiti Srpsku čitaonicu u Irigu i Istorijski arhiv Srema u Sremskoj Mitrovici, koji poseduje obimnu, mada nesređenu i nekompletnu arhivsku građu o Rudniku mrkog uglja „Vrdnik“. 


\section{Martinov}

Slovenačka polka na Fruškoj gori...

Izvori

Istorijski arhiv Srema, Sremska Mitrovica

Srpska čitaonica u Irigu

\section{Literatura}

Centralni registar spomenika kulture. Dostupno na: http://www.heritage. gov.rs/latinica/nepokretna_kulturna_dobra.php (15.09. 2017).

Dević, Antun i Blaž Zmajić. 2010. Župa Irig. Novi Sad : Samizdat.

Dević, Vojislav, Biserka Komnenić, Hristina Mikić. 2015. Novi kreativni prostori Vojvodine. Novi Sad : Zavod za kulturu Vojvodine.

Knežević, Aleksandar. 2014. Demographic characteristics of Slovenians in Vojvodina at the beginning of the XXI century. Zbornik Matice srpske za društvene nauke 148: 433-442.

Marković, Željko. 2014. Vrdnik, međunarodna priča. Novi Sad : Samizdat.

Matošević, Andrea. 2011. Pod zemljom. Antropologija rudarenja na Labinštini u XX. stoljeću. Zagreb : Institut za etnologiju i folkloristiku i Sveučilište Jurja Dobrile u Puli.

Ostojić, Milenko. 1989. Nepokoreni. Hronika Vrdnika i okoline. Ruski Krstur : SUBNOR i dr.

Petrović, Tanja. 2013. Museum and Workers: Negotiating Industrial Heritage in the Former Yugoslavia. Narodna umjetnost : hrvatski časopis za etnologiju i folkloristiku 50/1 : 96-120.

Stanovništvo. 1982. Popis stanovništva, domaćinstava i stanova 1981 godine : osnovna obeležja po opštinama. Statistički bilten 101. Novi Sad : Pokrajinski zavod za statistiku, SAP Vojvodina.

Vulin, Dragica. 2010. Rudnik mrkog uglja Vrdnik (1804-1968). Glasnik istorijskog arhiva grada Novog Sada 4: 80-102.

Šams, Franc. 2013. Istorija Srema i Petrovaradina. Novi Sad : Muzej grada Novog Sada. 
Vojislav Martinov

Muzej Vojvodine

Novi Sad, Srbija

vojislav.martinov@muzejvojvodine.org.rs

\section{SLOVENSKA POLKA NA FRUŠKI GORI: SLOVENSKI RUDARJI V RUDNIKU OGLJA V VRDNIKU}

Prvi slovenski priseljenci so v vas Vrdnik prispeli v sedemdesetih letih 19. stoletja, in sicer kot strokovna delovna moč za potrebe eksploatacije na novo odprtih kopov rudnika oglja v lastništvu zagrebške podjetniške družine Pongrac. V manjših valovih se je priseljevanje slovenskih rudarjev nadaljevalo tudi v začetku 20. stoletja, sinhrono z razmahom rudnika, ki je svoj vrhunec doživel $\mathrm{v}$ obdobju med dvema svetovnima vojnama. $\mathrm{V}$ članku je podan kratek zgodovinski prikaz priseljevanja (in izseljevanja) slovenskih prebivalcev, s poudarkom na karakteristikah njihovega življenja $\mathrm{v}$ večnacionalnem industrijsko-agrarnem Vrdniku, kot tudi na materialnih pričevanjih o kulturnem življenju celotne rudarske skupnosti.

Ključne besede: industrijska dediščina, Slovenci, zgodovina rudarstva, Vrdnik

Vojislav Martinov

Museum of Vojvodina

Novi Sad, Serbia

vojislav.martinov@muzejvojvodine.org.rs

\section{SLOVENIAN POLKA ON FRUŠKA GORA: SLOVENIAN MINERS IN THE COAL MINE IN VRDNIK}

The first Slovenian immigrants arrived in the village of Vrdnik in the 1870 s as professional labour force for the exploitation of the newly established coal mines, owned by the Zagreb-based entrepreneurial family Pongrac. Smaller waves of Slovenian miners continued to arrive in the early $20^{\text {th }}$ century, following the expansion of the mine, which reached its peak between the two world wars. This paper presents a brief historical overview of the immigration (and emigration) of the Slovenian population, while highlighting the characteristics of their life in the multiethnic industrial and agricultural Vrdnik, as well as on the material evidence of the cultural life of the mining community as a whole.

Keywords: industrial heritage, Slovenians, history of mining, Vrdnik 
V. Martinov

Slovenačka polka na Fruškoj gori:...

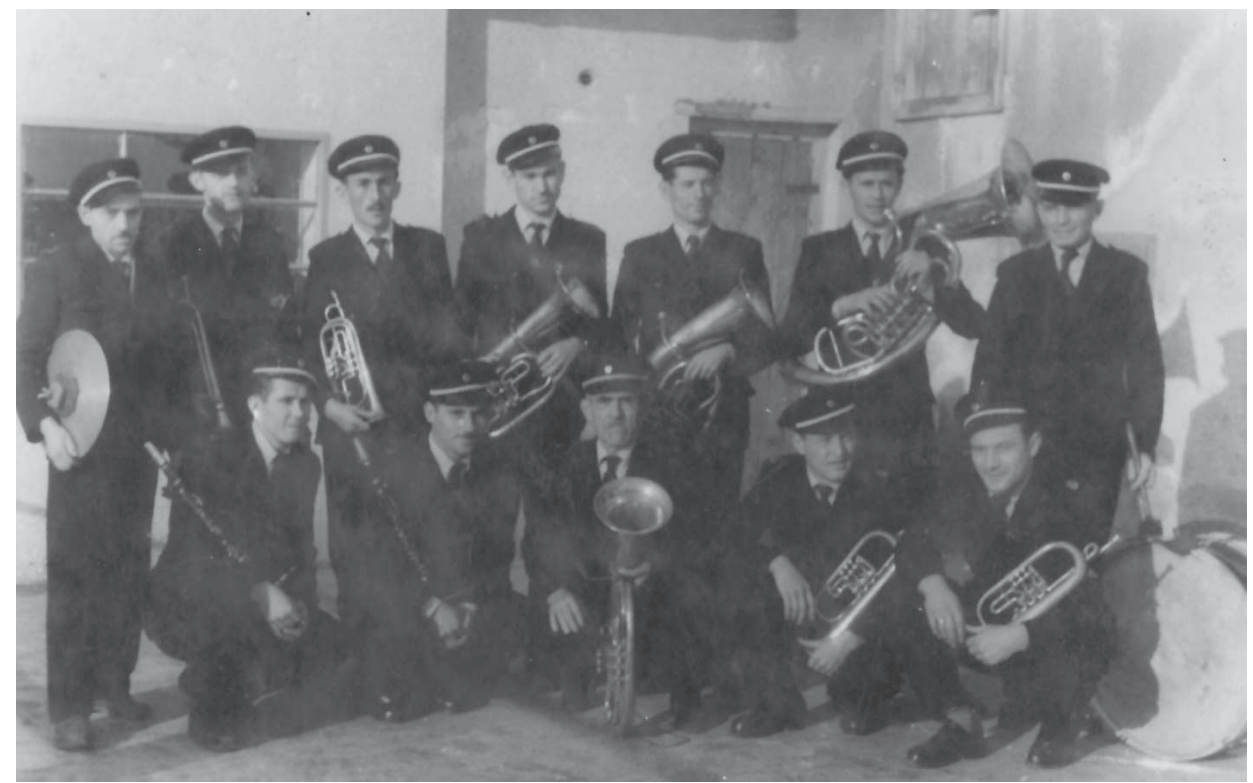

Slika 1. Rudarski orkestar u Vrdniku (Srpska čitaonica, Irig).

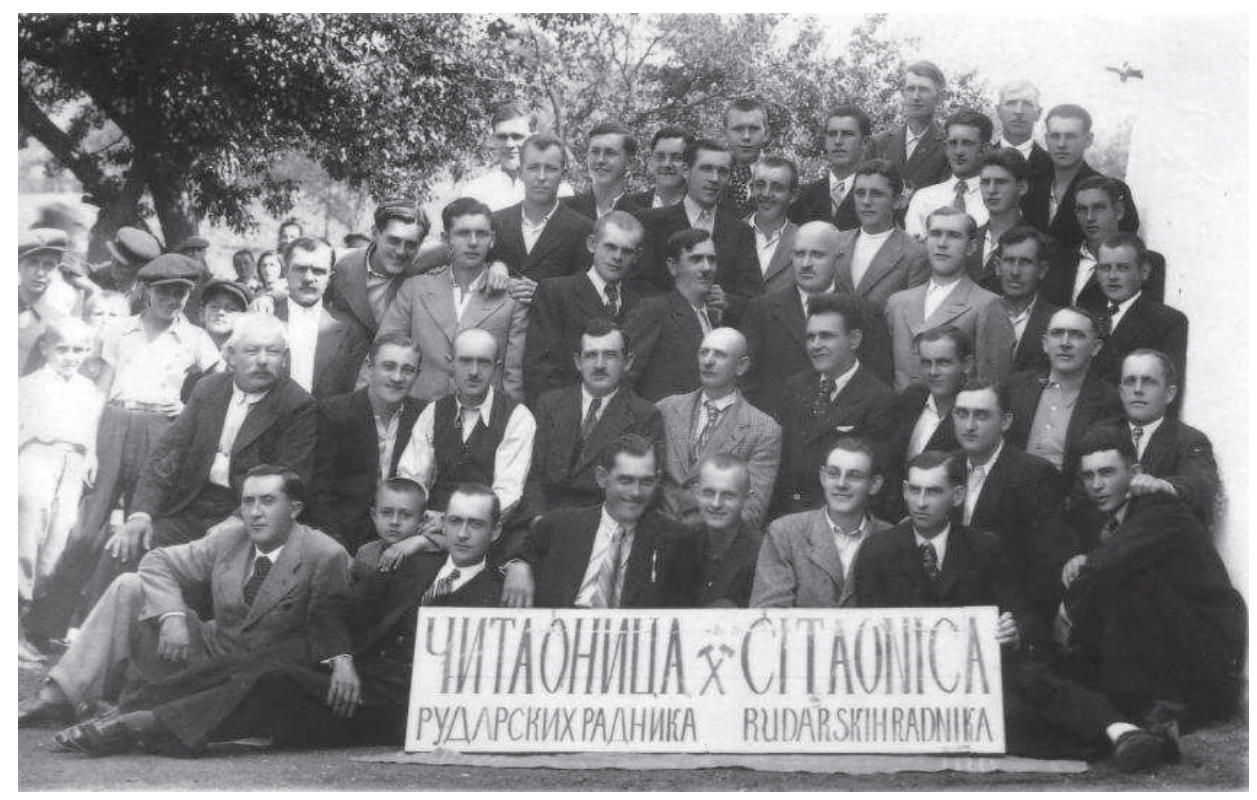

Slika 2. Grupni portret članova rudarske čitaonice (Srpska čitaonica, Irig). 

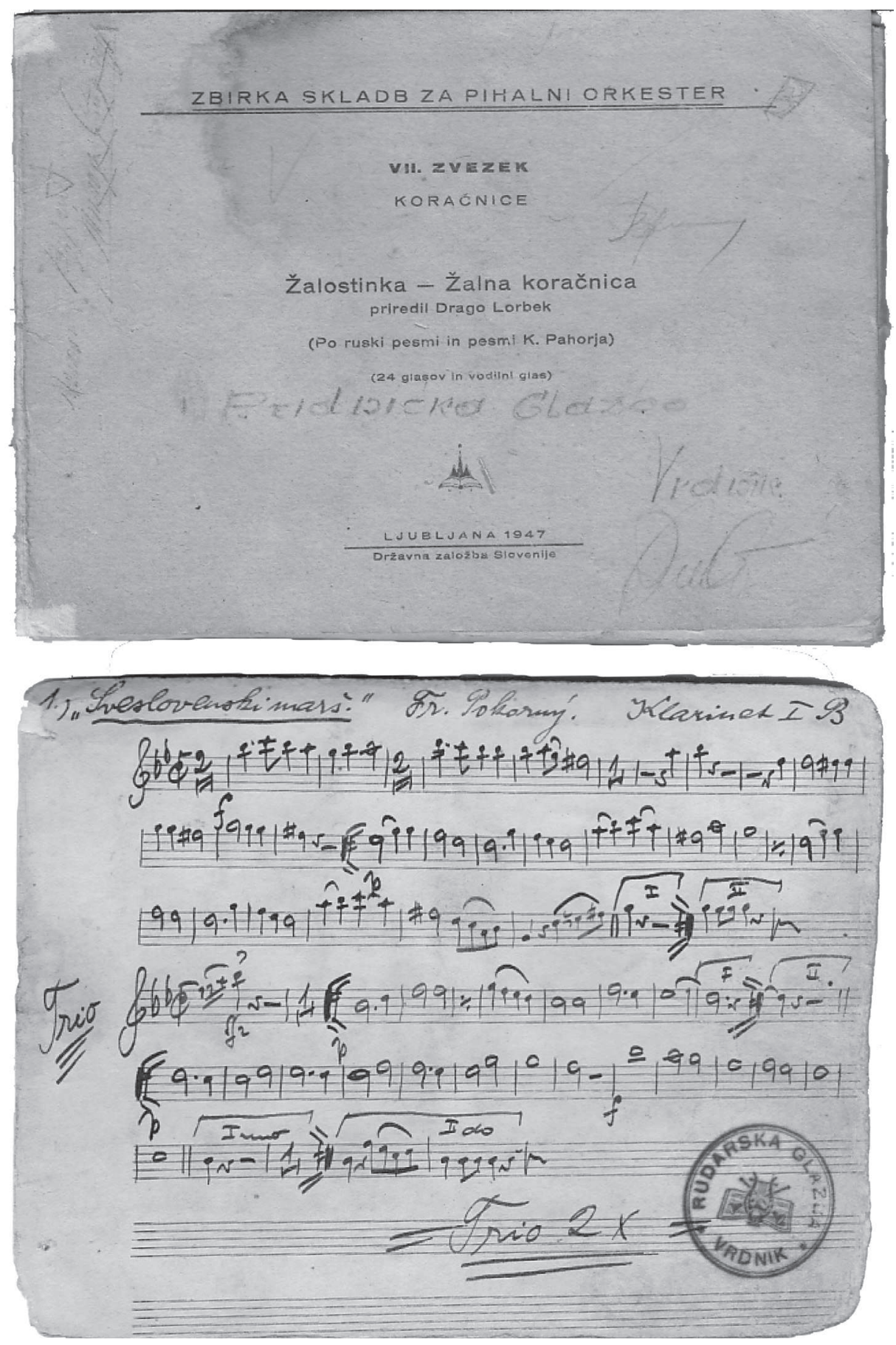

Slika 3. Notna sveska i zapis rudarskog orkestra (Srpska čitaonica, Irig). 